\title{
Board Governance, Ownership Structure and Foreign Investment in the Saudi Capital Market
}

\author{
Mohammed Bajaher ${ }^{1}$, Murya Habbash ${ }^{2, *}$ and Adel Alborr ${ }^{3}$ \\ ${ }^{1}$ Assistant Professor of Accounting College of Business, King Khalid University \& Aden University, Saudi Arabia. \\ ${ }^{2}$ Professor of Accounting, College of Business, King Khalid University, Saudi Arabia. \\ ${ }^{3}$ PhD candidate at Department of Accounting, King Khalid University, Saudi Arabia.
}

\begin{abstract}
Saudi vision 2030 targets, among other objectives, the attraction of foreign direct investment into the Saudi capital market. This paper examines whether board governance mechanisms and ownership structure play a role in foreign investors' decisions when buying shares in Saudi listed companies. Foreign investment in the Saudi capital market started in 2015 and reached a peak in 2019, with corporate governance regulations having been updated in 2017. We tested the proposed relationships using hand collected data for all Saudi non-financial firms in 2019.

While board governance is a critical mechanism in firms, this study found that it does not play a role in attracting foreign investment in the Saudi capital market. Foreign investors also seem to avoid firms with concentrated ownership that either have high government or director ownership; however, accounting and market variables show significant impact on foreign investors' decisions.

The outcomes of this study provide empirical evidence that current foreign investors in the Saudi stock market do not place enough merit on board governance and their investment decisions tend to depend on share performance. Thus, our results show that the current governance changes and capital market regulations in Saudi Arabia may not have been sufficient to stimulate the inflow of institutional foreign investment to the country to date, but rather they have attracted individual retail foreign investors.

These findings have crucial implications for foreign funds and Saudi market regulators as they highlight issues related to the Qualified Foreign Investor (QFI) program as well as researchers who work toward understanding foreign investors' behaviors in emerging markets.
\end{abstract}

Keywords: Board Governance, Ownership Structure, Foreign Investment, Saudi Capital Market.

\section{INTRODUCTION}

Recently, there has been an increased shift in foreign direct investment from developed to emerging markets. This can be attributed to the rapid growth of these emerging economies (Haider et al., 2016). Battena \& Vo (2015) argue that features of foreign investment behavior have become a vital part of financial market research since the significance of foreign investment in developing countries has become recognized.

One fundamental idea behind promoting corporate governance practices is the role they play in attracting foreign investments to the local economy, which in turn stimulates the economic growth of a country. Board governance and ownership structures are the most crucial firm-specific determinants of the good governance of a company (Khanchel, 2007). Thus, the purpose of the current study is to examine the impact of internal corporate governance (board

*Address correspondence to this author at Professor of Accounting, College of Business, King Khalid University, Saudi Arabia;

E-mail: mshabash@kku.edu.sa; governance and ownership structure) on foreign investment in Saudi non-financial listed companies. The board of directors is an internal corporate governance mechanism designed to ensure that the interests of shareholders and managers are closely aligned (Correia and Lucena, 2020). Board governance also reduces investment risks to foreigners by minimizing the costs of monitoring managers and controlling shareholders' exploitation of minority (foreign) shareholders (Shleifer and Vishny, 1997).

Empirical studies provide mixed evidence regarding the impact of board directors and ownership structure on foreign investments (Covrig et al., 2006; Leuz et al., 2009; Min \& Bowman, 2014; Miletkov, et al., 2014; Das, 2014; Yatim et al., 2016; Yeh, 2018; Badawi et al., 2019). Covrig et al. (2006) studied similarities and differences in the stock preferences of domestic and foreign fund managers for 11 developed countries. Their results show that the geographic allocations of foreign investments influence their stock preferences. Interestingly, they found different approaches based on geographic allocations among developed countries. In stock markets that have only recently opened up to foreign- 
ers, the factors that influence foreign investment may differ, so we expect to find further differences when examining a developing country using the Saudi context.

This empirical study is one of only a small number of studies to investigate the impact of internal corporate governance on foreign ownership in developing countries and the first in the Saudi context. In fact, most previous governance research in Saudi Arabia focused on how board governance and ownership structure influences firm performance. A review of the prior studies found that only Badawi et al. (2019) examined the determinants of foreign ownership among Saudi listed firms. Thus, the present investigation extends that study by examining the role of board governance in attracting foreign investors.

Our analysis provides evidence of significant negative relationships between government ownership and foreign ownership, which supports the claim that state- owned firms are less efficient and therefore less attractive to foreign investors. We also find that board ownership has a negative and significant impact on foreign investments in Saudi listed non-financial firms. This implies that foreign investors prefer to invest in companies with less board ownership. Finally, the results reveal that board governance is not associated with foreign ownership.

The paper proceeds as follows: Section 2 provides the institutional background; Section 3 reviews the literature and develops the research hypotheses; Section 4 describes the data and methodology; Section 5 discusses the empirical findings and Section 6 concludes the paper.

\section{INSTITUTIONAL BACKGROUND}

Today, the Kingdom of Saudi Arabia is the largest economy in the Middle East and North Africa, with a GDP of more than 780 billion dollars up to the end of 2018. The Saudi stock market (Tadawul) accounts for $76 \%$ of the market capitalization in the Middle East and North African (MENA) region and is ranked among the top 10 largest markets globally in terms of market capitalization.

In 2016, the Saudi government announced its Saudi Vision 2030, which aims to reduce the Saudi economy's dependence on oil. One of the specific goals of this vision is to increase foreign direct investment into the country. Saudi Arabia has recently pursued comprehensive economic reforms such as amending the Saudi Companies Act in 2015 and strengthening its corporate governance practices. On January 1, 2017, the Capital Market Authority (CMA) updated corporate governance regulations for public companies listed on the Saudi stock market. Strengthening corporate governance is one method being used by the Saudi government to boost investors' confidence and attract foreign investment (Habbash, 2016).

In 2019, three global indices, MSCI, FTSE and S\&P completed the process of including Tadawul in their emerging market indices. This was instrumental in bringing about the massive influx of Qualified Foreign Investor (QFI) that occurred during 2019, with the numbers almost quadrupling from 500 to 1,800 over the course of that year. Inclusion in the emerging market indices had a marked impact on foreign investor participation in 2019 with a 309\% increase in QFI registration value, $665 \%$ in QFI holdings value and $558 \%$ in QFI contribution to traded value.

In addition, the largest IPO in history took place in late 2019 when ARAMCO (the largest company exporting crude oil globally) was included in the Saudi stock market, a listing which is expected to uplift the liquidity in the market and attract new foreign investment portfolios. Through the QFI program, international investors have direct and consistent access to the Saudi capital market. The program was introduced in June 2015 and amended in June 2019 to ease registration requirements and expand the range of eligible foreign institutional investors.

No QFI may own $10 \%$ or more of the shares of any issuer whose shares are listed, or convertible debt instrument of the issuer. In addition, no more than $49 \%$ of an issuer may be owned in aggregate by foreign investors, except for foreign strategic investors. Entities eligible for QFI status include banks, brokerage and securities firms, insurance companies, investment funds, and government and government-related entities and prospective QFIs must be licensed or subject to regulatory oversight. With the exception of governmentrelated entities, applicants must have assets under management of at least $\$ 500$ million. As of October 2019, more than 1,500 international financial institutions have registered as QFIs.

\section{LITERATURE REVIEW AND HYPOTHESES DE- VELOPMENT}

The absence of previous investment experience in the markets which are newly open to foreigners, and the risks inherent in the lack of information available, might discourage investors. Yatim et al. (2016, p.151) stated: "The possible implication of corporate governance and agency costs on investment decisions may vary across investor groups. The effects of corporate governance may differ between foreign investors and domestic investors as the former group of investors are more likely to assign higher monitoring costs than the latter group. Therefore, foreign investors favor firms that they invest into put in place strong corporate governance structures more than domestic investors do".

In the corporate governance literature, agency theory is considered the driving theory. It describes the fundamental conflict between self-interested managers and owners. Jensen and Meckling (1976) argue that the separation between owners and managers causes conflict of interests. To mitigate this conflict, the board of directors is often perceived as the main tool for controlling executive management and applying incentives to encourage them (Romano \& Guerrini, 2014). Foreign institutional investors generally have large shareholdings so they may be exposed to more severe capital losses. Hence, to mitigate any possible conflict of interests and to reduce monitoring costs, foreign institutional investors are attracted to firms with good governance (Aggarwal et al., 2005; Leuz et al., 2009).

The board of directors is central to good corporate governance, due to its role in defining firms' strategies and having a significant advisory and monitoring role (Adams et al. 2010; Agrawal and Knoeber, 2001). The effectiveness of a board of 
directors can be determined by its structure (Ntim et al., 2017). Hence, board governance can be regarded as a valid signal of responsible management and protection of shareholders (Certo et al., 2001).

Min \& Bowman (2014) investigated whether the change in the corporate governance system affected firm foreign ownership in South Korea. They found that corporate governance changes can stimulate globalization and the inflow of foreign portfolio investment into a country. Board size is considered an important aspect of board governance which plays a vital role in achieving a good corporate governance structure (Paniagua et al., 2018; Tulung \& Ramdani, 2018). According to agency view, smaller boards are more effective in monitoring (Pillai and Al-Malkawi, 2018), whereas, as suggested by resource dependence theory, larger boards have better accessibility to external opportunities and resources and bring various experience, skills and knowledge (Dalton et al., 1999; Coles et al., 2008). According to the Saudi Corporate Governance Code, board should consist of not less than three and not more than 11 members.

Empirical studies reveal mixed results in terms of the impact of board size on performance. Dalton et al. (1999), conducted a meta-analysis of 27 studies and found that larger boards were associated with higher levels of firm performance. Beiner et al. (2006) found similar results, as did a recent study by Zhou et al. (2018) which reported that large-sized boards performed better in a study of Greek listed firms. However, Bajaher (2019) and Habash \& Bajaher (2015) found that large board size has a positive but insignificant association with financial performance in Saudi firms. Regarding the relationship between board size and foreign ownership, Yeh (2018) investigated the association between foreign institutional ownership and board size in Taiwan listed tourism firms and found that board size negatively and significantly influenced the ownership proportion of foreign institutional investors.

Another attribute examined in the present research is board independence. Agency theory argues that board independence is more likely to provide vigilant supervision which reduces opportunistic behavior by management, mitigates the agency problem, and protects shareholders' interests (Fama \& Jensen, 1983; Jensen \& Meckling, 1976; Dalton et al., 1999). In addition, the existence of independent directors on a firm's board offers superior diversity, expertise and experience which enhances the firm's reputation. Balachandran and Williams (2018) state that an independent director helps a firm to supervise executive management, while Bansala and Thenmozhi (2020) argue that an independent board can solve the agency problem of controlling shareholders and minority shareholders, as independent directors act as substitutes for external audit quality (Jiraporn et al., 2018). Muniandy and Hillier (2015) found there is a positive influence by independent directors on a firm's performance, and Bird et al. (2018) reported that board independence contributes to less variability in a firm's performance. Miletkove et al. (2014) showed there is a positive and significant association between board independence and foreign ownership, especially in countries with less developed legal institutions and poor external protection of investor rights.
In the Saudi context, Habbash (2012) demonstrates that firms with a higher proportion of independent board members are less likely to manage earnings. Bajaher (2019) found that board independence has a negative but insignificant effect on the financial performance of Saudi firms. However, Zhou et al. (2018) found that Greek listed firms with more independent board members performed poorly. In Malaysia, Yatim et al. (2014) studied the impact of board independence on foreign shareholdings in 777 listed firms for the financial year 2008 and found a positive but weak relationship between board independence and foreign shareholdings. However, they demonstrate that this is true for all categories of institutional investors, while there is no relation between noninstitutional investors and independent boards. This finding confirms that foreign ownership is not a homogenous group and their behavior differs according to the foreign investor type. Another study conducted by Yeh (2018) found there is a negative insignificant relationship between board independence and foreign ownership.

In terms of ownership structure, the underlying argument of agency theory here is that director ownership contributes to aligning directors' interests with those of shareholders (Norman, \& Rose, 2013) and this may send a signal to foreign investors that the interests of owners and managers are aligned. Empirical studies report mixed findings with respect to the influence of board ownership on performance. For instance, Mousa (2010) found no statistically significant relation between director ownership and firm performance, while Muttakin et al. (2012) reported a significant negative association between board ownership and firm performance. Hanafi et al. (2018) reported significant positive association between director ownership and firm performance. Similarly, Bajaher (2019) documented a positive and significant impact of director ownership on financial performance. Yeh (2018) also confirmed a positive and significant effect of director ownership on foreign ownership.

Badawi et al. (2019) studied the impact of government ownership on foreign shareholding in Saudi listed firms using data from 2015. They found that government ownership has a negative and significant effect on foreign ownership. They concluded that foreign investors do not choose to invest in state-owned firms. Based on Meyer and Peng (2016), government firms are less efficient in assets management than their counterparts. In general, Kim et al. (2010) reveal that foreign ownership is negatively related to firms' ownership concentration. From the above-mentioned discussion, the following hypotheses were proposed in order to achieve the study objectives.

H1: there is a significant positive association between board size and foreign ownership

H2: there is a significant positive association between board independence and foreign ownership.

H3: there is a significant positive association between chairperson independence and foreign ownership

H4: there is a significant negative association between government ownership and foreign ownership.

H5: there is a significant positive association between board ownership and foreign ownership. 
BASED ON THESE HYPOTHESES, THE FOLLOWING MODEL WAS DEVELOPED:

FOROWN $\mathrm{j}=\gamma 0+\gamma 1$ BRDSIZE $\mathrm{jt}+\gamma 2$ BRDIND $\mathrm{jt}+\gamma 3$ CHAIRIND jt $+\gamma 4$ GOVOWN

$\mathrm{jt}+\gamma 5 \mathrm{BRDOWN} \mathrm{jt}+\gamma 6 \mathrm{AGE} \mathrm{jt}+\gamma 7 \mathrm{BIG} 4 \mathrm{jt}+\gamma 8 \mathrm{RE}-$ TEAR jt $+\gamma 9$ SIZE jt $+\gamma 10$ LEVRG jt $+\gamma 11$ ROA jt $+\gamma 12$ PBV jt $+\gamma 13$ BIG4 jt

Where FOROWN is foreign ownership. BRDSIZE is board size. BRDIND is board independence. CHAIRIND is chairperson independence. GOVOWN is government ownership. BRDOWN is board directors' ownership. AGE is firm age. RETEAR is returned earning. SIZE is firm size. LEVRG is leverage. ROA is return on assets. PBV is price to book value. BIG4 is audit quality.

\section{METHODOLOGY SAMPLE}

The population of this study consists of listed firms in the Saudi stock market (Tadawul). The study used 2019 data, as the Saudi (QFI) program was considerably changed by relaxing some of the requirements for foreign investors in that year. Also, the inclusion of the Saudi capital market in two global indices took place in 2019 together with the announcement of the third global indices (FTSE), which had a marked impact on foreign investor participation. In 2019 there was an increase of 309\% in QFI registration, a value increase of $665 \%$ in QFI holdings, and a value increase of $558 \%$ in QFI contribution to traded value.

We excluded all firms operating in the banking and financial sectors, as accounting of certain items in financial statements is handled differently. Moreover, these firms have additional requirements and governance structures that are regulated by the Saudi monetary authority which are different than the rest of the Saudi listed firms. In addition, the omission of financial firms is consistent with analyses carried out in previous similar studies (Yatim at al., 2014; Badawi et al., 2019). Five companies, in which foreign investment is disallowed in their articles of association because of their geographical location in the holy cities of Makkah and Madinah, were also excluded from the sample. The final sample consists of 138 firms drawn from thirteen industries as classified by Tadawul. Data for ownership, board characteristics and firm-specific variables were collected manually from annual reports available at Tadawul website (www.tadawul.com.sa).

Table 1 presents the composition of the sample and shows that foreign institutional investors prefer to invest in sectors such as transportation, health care equipment \& svc, telecommunication services and retailing. The data also shows that some industries are under-weighted by foreign investors such as consumer durables \& apparel and diversified financials. All companies in our sample across all sectors have foreign shareholdings.

Table 1. Sample Selection

\begin{tabular}{|c|c|c|}
\hline Sector & No. of Firms & $\begin{array}{c}\text { Average Foreign } \\
\text { Ownership }\end{array}$ \\
\hline Energy & 5 & $4 \%$ \\
\hline Materials & 40 & $5 \%$ \\
\hline
\end{tabular}

\begin{tabular}{|c|c|c|}
\hline Capital Goods & 12 & $4 \%$ \\
\hline Commercial \& Professional Svc & 3 & $5 \%$ \\
\hline Transportation & 5 & $8 \%$ \\
\hline Consumer Durables \& Apparel & 6 & $1 \%$ \\
\hline Consumer Services & 11 & $5 \%$ \\
\hline Media and Entertainment & 2 & $3 \%$ \\
\hline Retailing & 8 & $6 \%$ \\
\hline Food \& Staples Retailing & 4 & $5 \%$ \\
\hline Food \& Beverages & 12 & $4 \%$ \\
\hline Health Care Equipment \& Svc & 7 & $8 \%$ \\
\hline Pharma, Biotech \& Life Science & 1 & $4 \%$ \\
\hline Real Estate Mgmt \& Dev't & 11 & $3 \%$ \\
\hline Software \& Services & 1 & $3 \%$ \\
\hline Telecommunication Services & 4 & $7 \%$ \\
\hline Utilities & 2 & $4 \%$ \\
\hline Diversified Financials & 4 & $2 \%$ \\
\hline Total & 138 & $47 \%$ \\
\hline
\end{tabular}

\section{MEASURING FOREIGN OWNERSHIP}

The dependent variable of this study is foreign ownership. Prior studies define foreign ownership as the ratio of shares held by foreign shareholders to total shares outstanding (Bokpin and Isshaq, 2009; Yatim at al., 2014; Badawi et al., 2019). Following previous studies, this study measures foreign ownership in the same way.

\section{BOARD GOVERNANCE AND OWNERSHIP STRUC- TURE VARIABLES}

The independent variables of the present paper is board attributes and ownership structure. Similar to previous studies (Bokpin and Isshaq, 2009; Yatim at al., 2014; Badawi et al., 2019), we measure independent variables as follows: board size is measured as the total number of directors sitting on the board; board independence is measured as the ratio of independent directors to the total number of board directors; chairperson independence is measured as 1 if the chairperson is independent and 0 otherwise; board ownership is measured as the ratio of total shares owned by directors to the total number of shares outstanding; and finally, government ownership is measured as the ratio of total number of shares owned by government to the total number of shares outstanding.

\section{CONTROL VARIABLES}

This study has several control variables, in accordance with prior studies related to foreign ownership. These variables are related to either stock characteristics or firm characteristics. Zou et al. (2016) investigated the preferences of both domestic and foreign institutional investors in China and 
found that foreign institutional investors tend to invest in large-sized, older firms with better accounting performance.

Firm size is defined as the natural log of total assets. Leverage is used as a control for the firm capital structure and financial vulnerability and is measured as total liabilities divided by total assets. Firm age is measured as the number of years since the company was established. Audit quality increases investors' confidence in the quality of financial reporting, therefore we measure audit quality by using a dummy variable of 1 if the firm financial statements are audited by one of the Big Four, and 0 otherwise. For accounting performance, we use returned earning measured as the ratio of returned earning divided by assets. In addition, return on assets (ROA) is measured as net income divided by total assets. Finally, price to book value is used as a market performance measure for growth opportunity.

\section{FINDINGS}

\section{Descriptive Statistics}

Table 2 reports the descriptive statistics (minimum, maximum, means, and standard deviation) for the variables. It shows that foreign ownership as a dependent variable ranges between a minimum of $.018 \%$ to a maximum of $22.5 \%$ with a mean of $4.47 \%$ and median of $3.5 \%$. Foreign ownership average in Saudi firms is considered low compared to the maximum allowable foreign ownership in listed Saudi companies, which is $49 \%$. Badawi et al. (2019), using data from 2015 , found that the average of foreign ownership among Saudi listed firms was about 2.13\%. In late 2015 the Saudi stock market authority allowed foreign investment in the Saudi market. The average foreign ownership in Saudi companies is considered low compared to other developing countries; for example, the mean foreign ownership in Malaysia was $6.78 \%$ in 2008, in Korea it was $9.26 \%$ in 2003 and the Taiwan tourism industry was $13.47 \%$ in 2015 according to Yatim et al. (2016), Min \& Bowman (2014), and Yeh (2018) respectively.

Table 2. Descriptive Statistics.

\begin{tabular}{|c|c|c|c|c|c|}
\hline Variable & MIN & MAX & MEAN & MEDIAN & SD \\
\hline FOROWN & 0.018 & 22.460 & 4.691 & 3.510 & 4.179 \\
\hline BRDSIZE & 3 & 11 & 8 & 8 & 1.57 \\
\hline BRDINDP & 0.00 & 0.87 & 0.44 & 0.42 & 0.14 \\
\hline CHAIRINDP & 0.00 & 1.00 & 0.21 & 0.00 & 0.40 \\
\hline GOVOWN & 0.00 & 70.00 & 6.07 & 0.00 & 16.10 \\
\hline BRDOWN & 0.00 & 95.28 & 8.36 & 0.75 & 16.70 \\
\hline AGE & 7 & 67 & 31 & 30 & 14 \\
\hline BIG4 & 0.00 & 1.00 & 0.45 & 0.00 & 0.50 \\
\hline RETEAR & -0.18 & 0.41 & 0.06 & 0.02 & 0.10 \\
\hline SIZE & 7.88 & 12.17 & 9.38 & 9.32 & 0.73 \\
\hline LEVRG & 0.00 & 0.69 & 0.18 & 0.14 & 0.15 \\
\hline
\end{tabular}

\begin{tabular}{|c|c|c|c|c|c|}
\hline ROA & -35.63 & 23.29 & 1.52 & 1.77 & 9.13 \\
\hline PBV & 0.48 & 6.17 & 1.90 & 1.32 & 1.40 \\
\hline
\end{tabular}

Regarding board size, Table 2 also shows that the minimum number of board members for Saudi listed non-financial firms is three and the maximum is 11 with a mean of 8.03 members. This is in line with the recommendations of the Saudi Corporate Governance Code (2017). The average of $44 \%$ independent board directors indicates that Saudi firms exceed the Corporate Governance Code requirement which states that at least one third of the board must comprise independent directors. The average of independent chairperson is $21 \%$, which indicates that about one fifth of the sampled firms have an independent chairperson which is not required by Saudi Corporate Governance Code. With respect to government ownership and board ownership, the mean is $6 \%$ and $8.3 \%$ respectively; the government ownership has not changed considerably from 2015, according to Badawai et al.'s (2019) study which documented a mean of 7\%. Finally, Table 2 also shows descriptive statistics for control variables. The average firm age is 31 years in about half of the sample firms audited by one of the Big 4. This shows that the average firm size is 9.3 and the standard deviation 0.73 , indicating that that there is no significant variation in size among the sampled firms.

Table 3. Variance Inflation Factor.

\begin{tabular}{|c|c|c|}
\hline Variable & VIF & $\mathbf{1 / V I F}$ \\
\hline SIZE & 2.80 & 0.35676 \\
\hline GOVOWN & 1.80 & 0.55697 \\
\hline ROA & 1.54 & 0.65035 \\
\hline LEVRG & 1.44 & 0.69521 \\
\hline BIG4 & 1.41 & 0.70914 \\
\hline BRDSIZ & 1.35 & 0.73840 \\
\hline BRDOWN & 1.32 & 0.75571 \\
\hline BRDIND & 1.32 & 0.75811 \\
\hline CHAIRINDP & 1.28 & 0.77959 \\
\hline RETEAR & 1.24 & 0.80373 \\
\hline PBV & 1.24 & 0.80722 \\
\hline AGE & 1.08 & 0.92176 \\
\hline Mean VIF & & 1.49 \\
\hline
\end{tabular}

\section{Correlations and Multicollinearity Analysis}

Multicollinearity in independent variables has been detected through analysis of correlation factors and variable inflation factors (VIF). Table 4 presents the correlation matrix of the dependent and independent variables, from which it has been observed that the highest simple correlation between independent variables was 0.60 between firm size and governmental ownership. By comparing the findings in Table 4 
Table 4. Correlation Matrix.

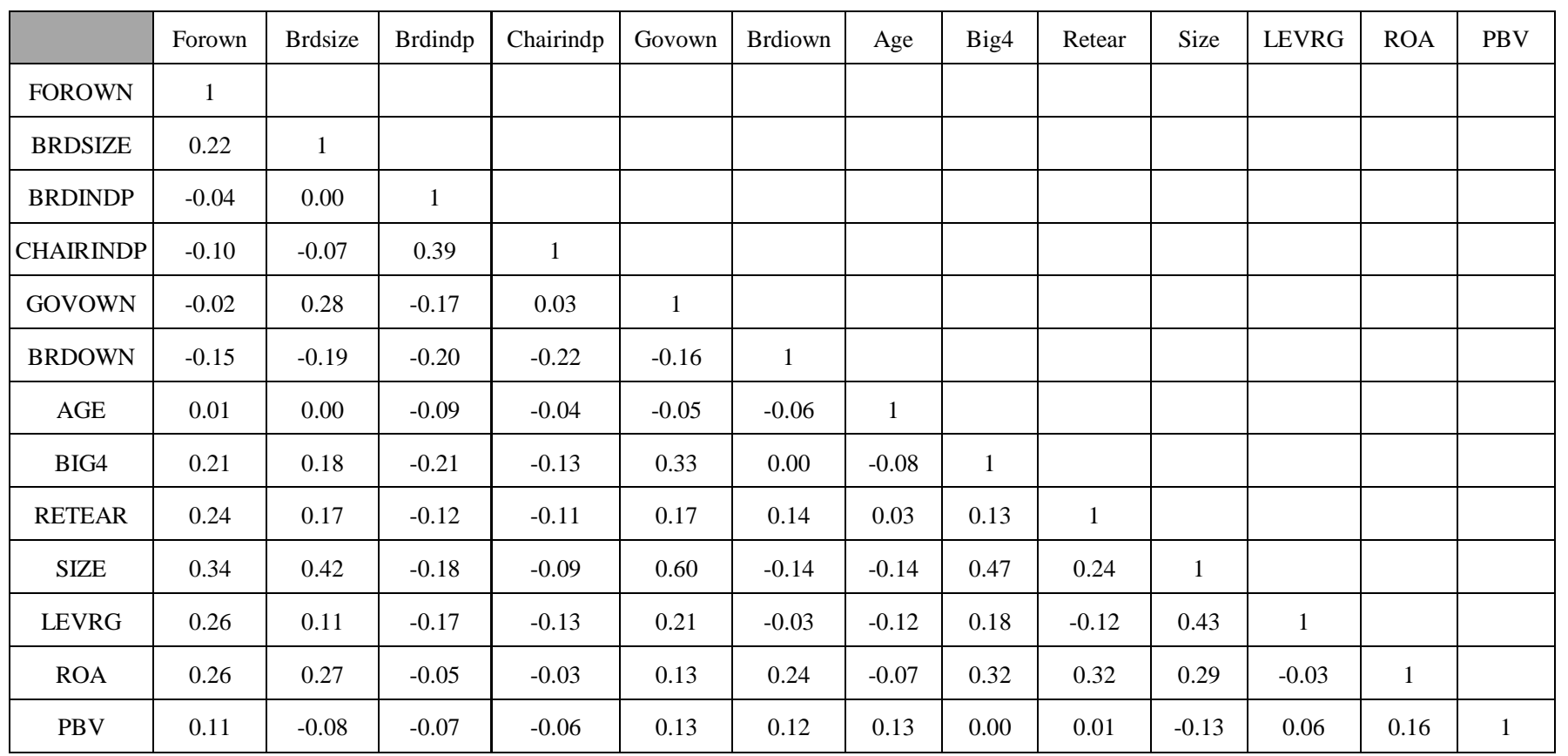

with level of multicollinearity of 0.80 , as suggested by Hair et al (2006), it is plausible to claim that serious multicollinearity does not exist among regressed variables. In addition, as reported in Table 3, the average VIF (1.49) is lower than 2 , which means that no sign of multicollinearity exists among the variables (Hair et al., 2006).

\section{Regression Results}

This is a cross sectional study investigating the effect of multi independent variables on foreign ownership as a dependent variable. Using ordinary least square analysis (OLS), we tested the hypotheses of this study as shown in Table 5. For further analysis, OLS robust and Tobit regressions were also conducted. The R-square of the OLS model was 35\%, while the OLS robust model had an adjusted R-square of $28.7 \%$, and the F-value of the model was statistically significant at the $1 \%$ level. Overall, the model explains about $35 \%$ of variance in foreign ownership. The R-square was higher than that found by Bawadi et al. (2019) which may be explained by the different variables used in this study; however, the Rsquare of this study is comparable to prior studies such as Miletkov et al. (2104) who had an R-square of $28 \%$.

As reported in Table 5, the OLS model showed that there is a positive but insignificant relationship between foreign ownership and board size. This result is in line with prior studies in the Saudi context, which found that board size is not related to financial performance. This finding is in contrast with those of Yeh (2018), who found that board size is negatively and significantly related to foreign ownership. However, it is consistent with Miletkov et al. (2104) who examined the effect of board structure on foreign ownership in a study of 80 countries.

The models show there is an insignificant positive relationship between foreign ownership and board independence. This result is inconsistent with Miletkov et al. (2104) and
Min \& Bowman (2015) who found that board independence has a positive and significant impact on foreign ownership. Miletkov et al. (2104) assert that the positive relation between board independence and foreign ownership is significantly stronger in countries with less developed legal institutions and poor external protection of investor rights. However, our result is similar to the findings of Yeh (2018) and Yatim et al. (2014). A plausible reason could be that the mandatory requirement of board independence leads foreign investors to consider it to be a regulation that firms must adhere to in order to meet listing requirements. Miletkov et al. (2104) mention that foreign institutional investors are undoubtedly sophisticated and should be able to distinguish between directors who are "independent" in name only and those who actively monitor company management.

In addition, the OLS analysis outcomes show that there is a positive but insignificant relationship between foreign ownership and chairperson independence. This result is inconsistent with $\mathrm{H} 3$, which predicted a positive and significant relationship between chairperson independence and foreign ownership. This result supports the previous finding of this study on the lack of effect of board independence on foreign ownership.

With respect to $\mathrm{H} 4$, which assumed a negative and significant relationship between foreign ownership and government ownership, the OLS result supports this assumption, in line with the findings of Badawi et al. (2019) who found a significant negative relationship between government ownership and foreign ownership in Saudi listed firms. Badawi et al. (2019) argue that foreign investors prefer to invest in nonstate-owned firms since such firms perform better than stateowned firms. Meyer and Peng (2016) argue that government ownership might indicate inefficient asset management. This result is also in line with the findings of Kim et al. (2010) who show that diffuse ownership leads to higher levels of foreign ownership in Korean companies. Miletkov et al. 
(2104) indicate that foreign investors are, on average, reluctant to invest in firms with concentrated ownership in most of their sample countries.

Finally, contrary to $\mathrm{H} 5$ that predicted a significant and positive relationship between foreign ownership and board ownership, the models report a significant but negative relationship between foreign ownership and board ownership. This result is in contrast with Yeh (2018), and opposes the viewpoint that, when directors become shareholders through share ownership, foreign investors are more likely to have more confidence in their vigilance. This may be due to the fact that in Saudi firms, such ownership is not merely director ownership but rather concentrated ownership by family members and controlling shareholders who sit on the board.

In terms of control variables, as shown in Table $\mathbf{5}$, firm age and BIG4 are not related to foreign ownership. Yatim et al. (2014) found a positive and significant association between foreign ownership and audit quality, as did Miletkov et al. (2104), who also found a negative relationship between foreign ownership and age. The audit quality result is in line with a prior study in the Saudi context by Habbash and Alghamdi (2017), which found no significant relationship between BIG4 and earnings management, confirming the well documented view in the literature that BIG4 audits are not necessarily superior since cases of audit failure by BIG4 can and do occur.

Furthermore, retained earnings, firm size, leverage, ROA and PBV have a positive and significant relationship with foreign ownership. This finding is consistent with Batten \& Vo (2015), Leuz et al. (2009), Min and Bowman, (2015) who found that firm size has a positive and significant effect on foreign ownership, supporting the notion that the larger the firm size, the more widely recognized and visible the firm will be and the wider analyst coverage it will receive. Covrig et al. (2006) also found similar results; however, in contrast with our study results they found a negative and significant relationship between leverage and foreign ownership. Bawadi et al. (2019) found that leverage has a positive but insignificant influence on foreign ownership in Saudi companies. Yatim et al. (2014) found a significant and negative association between firm size, book to market ratio and foreign ownership.

\section{Additional Analysis}

Several additional analyses were performed to confirm the robustness of the results. First, we divided the companies into big and small firms; the unreported results were similar. Second, we divided firms, according to performance, into profitable and loss- making firms and similar results were found. Third, OLS robust regression was performed. Robust fixed effect regression was conducted to avoid potential biases of omitted variables (Rousseeuw \& Leroy, 2003). Results were reported in column (II) of Table 5 and were similar to the outcomes of the OLS.

Finally, Tobit regression was also performed to address the bias toward a value of zero inherited in OLS regressions. The results of Tobit analysis are given in column (III) of Table $\mathbf{5}$. It is clear that the Tobit analysis results were similar to the main analysis in terms of statistical significance and coeffi- cient signs. The similar results indicate that the current outcomes were robust with different analysis techniques.

Table 5. Regression Models.

\begin{tabular}{|c|c|c|c|c|c|c|}
\hline \multirow{2}{*}{$\begin{array}{l}\text { Variable } \\
\text { FOROWN }\end{array}$} & \multicolumn{2}{|c|}{ (I) OLS } & \multicolumn{2}{|c|}{ (II) OLS Robust } & \multicolumn{2}{|c|}{ (III) Tobit regression } \\
\hline & Coefficient & $\begin{array}{c}\text { T Statis- } \\
\text { tics }\end{array}$ & Coefficient & $\begin{array}{c}\text { T Statis- } \\
\text { tics }\end{array}$ & Coefficient & $\begin{array}{c}T \text { Statis- } \\
\text { tics }\end{array}$ \\
\hline BRDSIZE & 0.111 & 0.570 & 0.11 & 0.64 & 0.06714 & 0.35 \\
\hline BRDINDP & 0.215 & 0.100 & 0.21 & 0.12 & 0.157488 & 0.08 \\
\hline CHAIRINDP & -0.306 & -0.420 & -0.31 & -0.54 & -0.22717 & -0.32 \\
\hline GOVOWN & -0.098 & $\begin{array}{c}-4.340 \\
* * *\end{array}$ & -0.10 & $-4.50 * * *$ & -0.09965 & $-4.55 * * *$ \\
\hline BRDOWN & -0.051 & $\begin{array}{c}-2.890 \\
* * *\end{array}$ & -0.05 & $-3.55 * * *$ & -0.05193 & $-3.02 * * *$ \\
\hline AGE & 0.009 & 0.480 & 0.01 & 0.54 & 0.011606 & 0.61 \\
\hline BIG4 & 0.436 & 0.700 & 0.44 & 0.64 & 0.387542 & 0.64 \\
\hline RETEAR & 0.654 & $2.490 * * *$ & 0.65 & $2.35 * *$ & 0.708486 & $2.76 * * *$ \\
\hline SIZE & 1.802 & $2.990 * * *$ & 1.80 & $2.79 * * *$ & 1.804719 & $3.09 * * *$ \\
\hline LEVRG & 4.055 & $2.050 * *$ & 4.05 & $2.16 * *$ & 4.515428 & $2.35 * *$ \\
\hline ROA & 0.059 & $1.670 *$ & 0.06 & $1.85 *$ & 0.060763 & $1.77 *$ \\
\hline PBV & 0.496 & $2.440 * * *$ & 0.50 & $2.31 * *$ & 0.500642 & $2.54 * * *$ \\
\hline -CONS & -15.668 & $\begin{array}{c}-2.800 \\
* * *\end{array}$ & -15.67 & $-2.64 * * *$ & -15.5525 & $-2.87 * * *$ \\
\hline \multicolumn{2}{|c|}{ Number of obs } & 133 & $\begin{array}{c}\text { Number of } \\
\text { obs }\end{array}$ & 133 & $\begin{array}{c}\text { Number of } \\
\text { obs }\end{array}$ & 133 \\
\hline \multicolumn{2}{|c|}{$F(12,120)$} & 5.45 & $F(12,120)$ & 11.12 & LR chi2(12) & 57.01 \\
\hline \multicolumn{2}{|c|}{ Prob $>F$} & 0 & Prob $>$ F & 0 & Prob > chi 2 & 0 \\
\hline \multicolumn{2}{|c|}{ R-squared } & 0.3527 & $\begin{array}{l}\text { Adj R- } \\
\text { squared }\end{array}$ & 0.2879 & Pseudo R2 & 0.0803 \\
\hline \multicolumn{2}{|c|}{ Root MSE } & 3.0089 & Root MSE & 3.0089 & $\begin{array}{l}\text { Log likeli- } \\
\text { hood }\end{array}$ & -326.4 \\
\hline
\end{tabular}

\section{CONCLUSION AND IMPLICATIONS}

This study examined the effects of board governance and ownership structure on foreign ownership using Saudi listed firms. The findings show a significant negative effect of government ownership on foreign ownership, which supports the well- established argument in the literature that stateowned firms are less efficient than those in the private sector and that privatization may attract foreign ownership. Further, board ownership is found to be negatively and significantly associated with foreign ownership. This result opposes the viewpoint that, when directors become shareholders through share ownership, foreign investors are more likely to have more confidence in their vigilance.

Board size, board independence and chairperson independence are found to be insignificantly related to foreign ownership. One plausible explanation here could be that vigilant 
supervision offered by boards may be substituted by other vigilant means used by foreign investors. Another reason might be that foreign ownership in Saudi listed firms is a short-term investment that focuses on market and accounting attributes rather than being a strategic investment, especially as we cannot separate the type of ownership in our study due to lack of disclosure. The current small percentage of foreign ownership in the Saudi market may support this view.

This view may also be supported by the positive results documented in this study between foreign ownership and other market and accounting variables, namely ROA, returned earnings and PBV. Interestingly, in studies that document a relationship between foreign ownership and corporate governance, they found no significant relationship between foreign ownership and other market and accounting variables. For example, Min and Bowman (2015) found no significant relationship between foreign ownership and market to book value and dividends in the Korean market. In addition, Yatim et al. (2016) found that board independence is ineffective in attracting foreign ownership, but that ROA has a significant impact on foreign ownership in Malaysia. Yeh (2018) reported similar patterns using Taiwanese listed tourism firms.

Miletkov et al. (2104) documented that the relationship between foreign ownership and independent directors is more significant for foreign institutional investors than for foreign non-institutional investors. Chung and Zhang (2011) also found that corporate governance considerations are less likely to affect the investment decisions of non- institutional investors because they are less likely to actively monitor the firms in which they invest and they are not subject to the same strict fiduciary responsibilities as institutional investors. Barber and Odean (2008) argue that individual investors mainly gravitate toward attention-grabbing stocks. Dahlquist and Robertsson (2001) conclude that most of the features associated with foreign ownership are driven by the fact that foreign investors typically are institutional investors; therefore, they believe there is an institutional investor bias rather than a foreign investor bias.

Overall, the results of this research provide empirical evidence that foreign owners in the Saudi stock market prefer large companies that do not have concentrated ownerships by government or directors and they pay less attention to board governance and more attention to share performance. Thus, our results show that the current governance changes and capital market regulations in Saudi Arabia may not be sufficient to stimulate the inflow of institutional foreign investment into the country.

Although we conducted a series of tests to prove the robustness of our results, they must be understood in light of a number of limitations. First, the present study focuses only on data from a one-year period. Future research could include more years starting from 2019. Second, the study excludes financial firms, whereas further studies could be conducted on banks and insurance firms. Finally, the fixedeffects regression model alleviates some endogeneity concerns, but the estimation is still subject to dynamic endogeneity in the sense that past values of foreign ownership may affect the degree of board governance and ownership structure. Certainly, using 2SLS analysis is a more effective tool to control for possible endogeneity problems, however it was not possible with the current data to conduct a 2SLS analysis to test for such problems.

Regardless of these limitations, the present study enriches the existing literature on corporate governance and foreign ownership by examining one of the top emerging markets. Given the critical role of foreign institutional investors in the global market, it is essential to track the factors that stimulate their investment decisions. In particular, the present study has implications for CMA in their aim to achieve Saudi 2030 vision by attracting institutional foreign investment, our results suggest that the Saudi stock market has not succeeded in attracting sufficient institutional foreign investors but rather individual retail foreign investors, and our results analyzed these retail foreign investors' current behavior in the Saudi stock market. Our results help to shed further light on the introduction and development of the (QFI) program in Saudi Arabia, and thus on the Saudi 2030 vision, and direct its efforts toward the liberalization of the financial market.

\section{ACKNOWLEDGMENTS}

The authors extend their appreciation to the Deanship of Scientific Research at King Khalid University for funding this work through the research group Project under grant number (R.G.P.1/116/40).

\section{CONFLICT OF INTEREST STATEMENT}

The authors declare that they have no conflict of interest.

\section{REFERENCES}

Adams, R. B., Hermalin, B. E., \& Weisbach, M. S. (2010). The role of boards of directors in corporate governance: A conceptual framework and survey. Journal of Economic Literature, 48(1), 58-107.

Agrawal, A., \& Knoeber, C. R. (2001). Do some outside directors play a political role?. The Journal of Law and Economics, 44(1), 179-198.

Alfatta, A. (2019). The Impact of the Shari'ah on Foreign Direct Investment and Arbitration: The Case of Saudi Arabia and its Vision 2030 (Doctoral dissertation, University of Westminster).

Badawi, A., Al Qudah, A., \& Rashideh, W. M. (2019). Determinants of foreign portfolio investment in emerging markets: evidence from Saudi stock market. Journal of Economics and Finance, 43(4), 779-794.

Bajaher M. S (2019). Corporate Governance and Financial Performance: An Empirical Study on Cement Companies Listed in Saudi Stock Market. Jerash for Research and Studies, 20 (2), 697-711.

Bansal, S., \& Thenmozhi, M. (2020). Does concentrated founder ownership affect board independence? Role of corporate life cycle and ownership identity. Pacific-Basin Finance Journal, 62, 101377.

Batten, J. A., \& Vo, X. V. (2015). Foreign ownership in emerging stock markets. Journal of Multinational Financial Management, 32, 1524.

Beiner, S., Drobetz, W., Schmid, M. M., \& Zimmermann, H. (2006). An integrated framework of corporate governance and firm valuation. European Financial Management, 12(2): 249-283.

Bird, R., Huang, P., \& Lu, Y. (2018). Board independence and the variability of firm performance: Evidence from an exogenous regulatory shock. Australian Journal of Management, 43(1): 3-26.

Certo, S. T., Daily, C. M., \& Dalton, D. R. (2001). Signaling firm value through board structure: An investigation of initial public offerings. Entrepreneurship Theory and Practice, 26(2): 33-50.

Correia, T.d.S. and Lucena, W.G.L. (2020). Board of directors and code of business ethics of Brazilian companies. RAUSP Management Journal, 55(2): 263-279.

Covrig, V., Lau, S. T., \& Ng, L. (2006). Do domestic and foreign fund managers have similar preferences for stock characteristics? A 
cross-country analysis. Journal of International Business Studies, 37(3): 407-429.

Dahlquist, M., \& Robertson, G. (2001). Direct foreign ownership, institutional investor, and firm characteristics. Journal of Financial Economics, 59)3(: 413-440.

Daily, C. M., Certo, S. T., \& Dalton, D. R. (1999). A decade of corporate women: Some progress in the boardroom, none in the executive suite. Strategic management Journal, 20(1): 93-100.

Dalton, D. R., Daily, C. M., Johnson, J. L., \& Ellstrand, A. E. (1999). Number of directors and financial performance: A meta-analysis. Academy of Management Journal, 42(6): 674-686.

Das, P. (2014). The role of corporate governance in foreign investments. Applied Financial Economics, 24(3): 187-201.

Ferreira, M. A., \& Matos, P. (2008). The colors of investors' money: The role of institutional investors around the world. Journal of Financial Economics, 88(3): 499-533.

Habbash, M. (2012). Corporate Governance Mechanisms and Earnings Management: Evidence from Saudi Arabia. Accounting Research. 11( 1): 49- 84 .

Habbash, M. (2016). Corporate governance and corporate social responsibility disclosure: evidence from Saudi Arabia. Social Responsibility Journal, 12(4): 740-754.

Habbash, M. and Alghamdi, S. (2017) Audit quality and earnings management in less developed economies: the case of Saudi Arabia. Journal of Management \& Governance, 21 (73): 351-373

Habbash, M. and Bajaher, M. (2015). An empirical analysis of the impact of board structure on the performance of large Saudi firms. Arab Journal of Administrative Sciences, 22 (1): 91-105.

Haider, M. and Abdulahi, E. (2016). Determinants of foreign portfolio investment and its effects on China. International Journal of Economics and Finance, 8(12):143-150.

Hair, J. F., Black, W. C., Babin, B. J., Anderson, R. E., \& Tatham, R. L. (2006).

Multivariate data analysis. Upper Saddle River, NJ: Pearson Education.

Hanafi, M.M., Setiyono, B. and Sanjaya, I.P.S. (2018). Ownership structure and firm performance: evidence from the subprime crisis period. Corporate Governance, 18 (2): 206-219.

Jiraporn, P., \& Lee, S. M. (2018). How do Independent Directors Influence Corporate Risk-Taking? Evidence from a Quasi-Natural Experiment. International Review of Finance, 18(3): 507-519.

Jensen, M.C. \& Meckling, W.H. (1976). Theory of the firm: managerial behavior, agency costs and ownership structure. Journal of Financial Economics, 3(4): 305-360.

Khanchel El Mehdi, I. (2007). Empirical evidence on corporate governance and corporate performance in Tunisia. Corporate Governance: An International Review, 15(6): 1429-1441.

Muniandy, B., \& Hillier, J. (2015). Board independence, investment opportunity set and performance of South African firms. Pacific-Basin Finance Journal, 35:108- 124.

Min, B. S., \& Bowman, R. G. (2015). Corporate governance, regulation and foreign equity ownership: Lessons from Korea. Economic Modelling, 47, 145-155.
Miletkov, M. K., Poulsen, A. B., \& Wintoki, M. B. (2014). The role of corporate board structure in attracting foreign investors. Journal of Corporate Finance, 29:143- 157.

Muttakin, M. B., \& Ullah, S. (2012). Corporate governance and bank performance: Evidence from Bangladesh.Corporate Board: Role, Duties \& Composition, 8(1): 62-68.

Mousa, G.A. (2010). An empirical analysis of the effect of managerial ownership and board characteristics on corporate performance: evidence from Egypt. Journal of Commerce and Finance, 2: 21-52.

Mensah, M. and Adams, M. (2014). The nexus between corporate governance and records management in private and public hospitals in Ghana. Records Management Journal, Vol. 24 (1):32-55.

Paniagua, J., Rivelles, R., \& Sapena, J. (2018). Corporate governance and financial performance: The role of ownership and board structure. Journal of Business Research, 89: 229-234.

Pillai, R., \& Al-Malkawi, H. A. N. (2018). On the relationship between corporate governance and firm performance: Evidence from GCC countries. Research in International Business and Finance, 44: 394-410.

Romano, G., \& Guerrini, A. (2014). The effects of ownership, board size and board composition on the performance of Italian water utilities. Utilities Policy, 31: 18- 28.

Rose, J. M., Mazza, C. R., Norman, C. S., \& Rose, A. M. (2013). The influence of director stock ownership and board discussion transparency on financial reporting quality. Accounting. Organizations and Society, 38(5): 397-405.

Shleifer, A., Vishny, R., 1997. A survey of corporate governance. The Journal of Financ, 52(2): 737-783.

Tulung, J. E., \& Ramdani, D. (2018). Independence, size and performance of the board: An emerging market research. Corporate Ownership \& Control, 15(2): 201-208.

Vargas, N. J. A. (2003). Robust estimation in multivariate control charts for individual observations. Journal of Quality Technology, 35(4): 367-376.

Yatim, P., Iskandar, T. M., \& Nga, E. (2016). Board attributes and foreign shareholdings in Malaysian listed firms. Journal of Management \& Governance, 20(1): 147-178.

Yeh, C. M. (2018). Does board governance matter for foreign institutional investors to invest in listed tourism firms?. Tourism Management, 68: 66-78.

Zhou, H., Owusu-Ansah, S., \& Maggina, A. (2018). Board of directors, audit committee, and firm performance: Evidence from Greece. Journal of International Accounting, Auditing and Taxation, 31: 20-36.

Zou, L., Tang, T., \& Li, X. (2016). The stock preferences of domestic versus foreign investors: Evidence from qualified foreign institutional investors in China. Journal of Multinational Financial Management, 37-38: 12-28. 